\title{
BUSINESS MODELS ANALYSIS IN THE CONTEXT OF HEALTH RESORTS ENTERPRISES ACTIVITY - LITERATURE REVIEW
}

\author{
ADAM R. SZROMEK, ${ }^{1}$ KRZYSZTOF HERMAN ${ }^{2}$ \\ Silesian University of Technology \\ 1 innowator@o2.pl \\ 2 krzyherman@gmail.com
}

\author{
\begin{tabular}{l|l} 
JEL CODES & L83, Z32, C45
\end{tabular} \\ KEYWORDS business models, health resorts, spa enterprises
}

ABSTRACT Background. The basic background of the conducted research was the need to modernize business models of spa enterprises. In many cases the lack of formalized business model can be noticed, while in some areas there are attempts to describe it. Yet, this is often a deceptive activity, forced by hurried introduction of market conditions into health resorts enterprises and an attempt to fit into difficult economic situation. Health resorts sector is still characterized by business models dependent on other entities creating their market system.

Research aim. The main aim of the article is the analysis of literature in the field of business modeling and business models classification, referring to the needs of spa enterprises.

Methodology. The basic methodology of the conducted research was critical analysis of literature. Key findings. Business models used in health resort facilities need to be re-defined in terms of components and business architecture, especially in terms of the occurring processes and relations, as the social changes, and with them the services reorganization in this sector, constitute the necessity to introduce changes to the health resort business model. Modern health resort business model should be targeted towards the market dependency of B2C (Business-to-Customer) type, creating especially value for the customer. Modern health resort enterprise business model should take into account changes in the health resort product structure and its components.

\section{Introduction}

The popularity of business models can be observed in numerous new academic papers concerning enterprises in which the managers attempt to identify new ways of running the business. It seems that the growing interest of practitioners and academics with business model results, first and foremost, from the turbulent environment in which the tourism enterprises operate. The necessity to adjust oneself to the dynamic changes taking place, among others, in the tourism consumers 
preferences and the rapid development of digital technologies forces the enterprises to look for the possibility to define a new formula of business model or to improve the existing one. Much thought is devoted to the possibilities of using new technologies, especially when presenting the tourism offer, creating values proposals or when establishing effective communication channels.

Business modeling is an issue discussed by the entrepreneurs ever since they started establishing their own businesses. Nevertheless, only a few decades ago the tendency to organize this process emerged, thus creating various approaches (taxonomic, diluted etc.) and taking into account various combinations of components and architecture (Doligalski, 2014, p. 20).

One of the most popular approaches to business modeling is the business analysis through its components, that is key activity, key partners, key resources, cost structure, relationship with customers, customer segmentation, proportions of values, channels and revenue streams (Osterwalder, Pigneur, 2010, pp. 24-45). Other approaches list such elements of business models as customer's choice, capturing value, strategic control and scope of activities (Slywotzky, Morrison, Andelman, 2000, pp. 388-392). Yet, no matter what is the adopted approach, business modeling requires diligent classification of key elements of that model, paying attention that they are up-to-date.

This problem is evident especially in Polish enterprises rendering health related services, notably in health resorts facilities (Zakład Lecznictwa Uzdrowiskowego - ZLU) which till 1990s were financed by the state budget (Szromek, 2011, pp. 85-114). Historical aspects of development of that sector prove how many changes the managers of these facilities had to face. Starting from the changes in the system of financing of these enterprises, which resulted from political changes, through health services reforms, which ZLU is a part of, being at the same time health care institution (Zakład Opieki Zdrowotnej - ZOZ), and ending with privatization of these facilities and their transformation into enterprises being subject to market competition rules.

Observations made by the authors indicate that in many cases the lack of formalized business model can be noticed, while in some cases there are attempts to describe it. Yet, this is often a deceptive activity, forced by hurried introduction of market conditions into health resorts enterprises and an attempt to fit into difficult economic situation. Health resorts sector is still characterized by business models dependent on other entities creating their market system. Therefore, there is a need to define a universal health resort business model with selective choice of elements of each of its components. The main aim of the article is the analysis of literature in the field of business modeling and business models classification, referring to the needs of health resorts enterprises.

\section{Business models and their classification}

Business model analysis indicates their diversity in the objective scope. They can be perceived as a synthetic description of business nature (Magretta, 2002) or as a business tool (Teece, 2017), image of relations between the components that lead to establishment and capturing of value through organization (Battistella, Toni, Zan, Pessot, 2017) etc. 


\section{Business models definititions}

J. Magretta (2002) presents a way of perceiving business models in descriptive category. In her view, business models resemble stories in their nature that explain how the enterprise operates. Similar approach is presented by J. Dworak (2016) who described business models emphasizing their usefulness when managing the enterprise, as a theoretical structure describing its activity based on selected factors.

The literature presents detailed definitions in the context of tool nature of business model. D. Teece (2017) perceives them as a tool describing the design or architecture of creation, supply or value capturing mechanisms. He also notes that the core of business model is defining the way in which the enterprise captures the value for the customers, entices them to pay for this value and converts payables into profits. S. Prendeville and N. Bocken (2017) perceive business model similarly. They described it as a conceptual tool describing the activities that refer to business transactions between customers, partners and suppliers and the organization and their participation in the development and capturing of value.

When paying attention to the tool character of business models, it was emphasized that they are not only used to describe the business reality, but also - when effectively used - to shape this reality. For that purpose, it was important to indicate elements of that model and relations that occur between them. It was emphasized by M. Geissdoerfer, P. Savaget and S. Evans (2017) who defined business model as a simplified representation of organization elements, together with interaction between these elements, in order to analyze, plan and communicate in the intricate organization structure. A similar approach is presented by M. Johnson, C. Christensen and H. Kagerman (1996) who describe it as interrelated elements, i.e. proposal of value, profit formula, key processes and resources that create and deliver the value.

An important element of defining business model is the need to pay attention to the main objective of business models creation, that is creating value for the customer and retaining the value as profit. Such a manner of perceiving business models is presented by for example T. Falencikowski (2012). He assumed that business model is a multi-component unit developed and separated to present in a simplified way the manner of running a business, by describing the logic of value creation for the consumer and capturing its part by the enterprise. B. Rusu (2016) also maintains the above assumption and understands the business model as a correlation system that enables the creation of value for customers, based on enhanced planning of architecture of the designed system and correlated activities. Similar views are expressed by L. Knop and J. Brzóska (2016, pp. 215-217) who in their approach to the business model focus on customers and what the enterprise can offer them. They describe business model as a configuration system of resources and activities (intercorrelated), covering among others creation of values that on the one hand need to satisfy the needs of the customer and on the other hand they need to be a source of revenue for the enterprise. A. Wiśniewski (2017, p. 76) presents a specific way of perceiving the revenue. He defines the business model by referring to the basic concepts and presents it as a description of construction, activity and correlations in a venture that generates profits. 
C. Batistella et al. (2017) have an interesting approach to this subject. They pay attention to the relations with other manager tools. They assume that the business model presents how the strategy is implemented by description of creation, supply and recording of economic, social or other values.

Description of relations with other manager tools and manner of value creation and capturing can occur in two ways: with the use of description or graphics. It is emphasized by M. Al.-Debei, R. El-Haddadeh and D. Avison (2008) who perceive business models as an abstract textual or graphic representation of interrelated structures of model architecture prepared by the organization and of all the products and services that the organization has in offer and that are essential to achieve its aim.

When forming a definition, some academics pay attention to the aspect related to competitiveness. B. Iwasieczko (2014) belongs to this group of academics who define business model as a configuration of business elements established to create value for the customers and to be an element of effective competition. B. Nogalski (2009) has similar views while also paying attention to the resources being a key aspect of an organization. He described business model as a characteristic of value for the customer, a set of basic resources, activities and relations with partners, the aim of which is to create this value and competitive advantage.

To summarize the presented literature references, it can be stated that modern ways of describing the nature of business models have a tool character, treating the business models as management tools and indicating their strategic meaning for the organization (Szromek, 2018).

\section{Business models classification}

Apart from discussing business models definitions, in the literature one can also find business models classifications. They organize their tool usability and explain scientific meaning of the description of organizational processes.

From among Polish researches who present interesting and extensive typology, J. Brzóska (2009, pp. 18-21) is worth mentioning. In his publication he presents four groups of business models (tab. 1).

Tahle 1. Business models types

\begin{tabular}{|c|c|c|c|}
\hline \multicolumn{3}{|c|}{ Business model types } \\
\hline $\begin{array}{c}\text { models based on the determi- } \\
\text { nants of profitability }\end{array}$ & $\begin{array}{c}\text { models exposing competitive } \\
\text { advantage }\end{array}$ & $\begin{array}{c}\text { business models as a unique } \\
\text { combination of resources render- } \\
\text { ing value and competitiveness }\end{array}$ & $\begin{array}{c}\text { business models using } \\
\text { innovation }\end{array}$ \\
\hline $\begin{array}{c}\text { model based on sectoral and } \\
\text { specific factors of the enterprise, } \\
\text { model of dynamic marketing } \\
\text { strategy, } \\
\text { model of economic } \\
\text { effectiveness }\end{array}$ & $\begin{array}{l}\text { - model of application creation } \\
\text { and maintaining competitive } \\
\text { advantage, } \\
\text { model combining competitive } \\
\text { advantage with operational } \\
\text { effectiveness }\end{array}$ & $\begin{array}{l}\text { - business model as a unique } \\
\text { combination of assets creating } \\
\text { value, } \\
\text { - model based on the competi- } \\
\text { tiveness potential }\end{array}$ & $\begin{array}{c}\text {-strategic model as a basis for } \\
\text { innovative business concept, } \\
\text { tion (Blue Ocean Strategy) }\end{array}$ \\
\hline
\end{tabular}

Source: own study on the basis of J. Brzóska (2009). 
The first group are models based on the determinants of profitability. The basic concept behind this group of models is the selection and configuration of factors generating profit and the aim of their usage is to achieve current and long-term profitability. Three models were distinguished in this group:

- model based on sectoral and specific factors of the enterprise,

- model of dynamic marketing strategy,

- model of economic effectiveness.

The second group is composed of models emphasizing competitive advantage. They are based on achieving competitive advantage through innovative activities creating value chain, and the aim of their functioning is to create, achieve and maintain constant competitive advantage. Two models were distinguished in this group:

- model of application creation and maintaining competitive advantage,

- model combining competitive advantage with operational effectiveness.

The third group combines models focused on creating and development of resources potential that can ensure competitiveness, with the main objective being the increase of value. In this group we can distinguish:

- business model as a unique combination of assets creating value,

- model based on the competitiveness potential.

The fourth group is characterized by models using radical innovations to create a value for the customer and increase the revenue of the enterprise. The objective of such designed business models is the increase of effectiveness and the development of the enterprise by establishing new market space. J. Brzóska considers the following models to constitute this group:

- strategic model as a basis for innovative business concept,

- model based on value innovation (Blue Ocean Strategy).

K. Obłój (2010, pp. 103-117) divided models into three groups. Distinguished models are the following: integrator, conductor and operator. Operator model is based on one aspect of the value chain. A research operator can be distinguished, one who deals with the development of new technologies, as well as production and marketing operator. A specific type is the navigator model, characteristic for companies operating via the Internet such as Amazon, eBay or Google, that generate profits having relatively small amount of resources. The integrator model is characterized by the need to control the most important assets and skills and the process of creation and appropriation of margins. The organizations using the integrator model (for example these from energy sector) control the stage of raw material acquisition, its transport, processing and sale, at the same time acquiring the margin of every link of the value chain. The last model is the conductor model that means a configuration based on the partners networks in which the least important elements of value chain are outsourced.

A. Osterwalder and Y. Pigneur (2010) have a completely different approach to the segmentation of business models. They propose five general categories, paying attention to common components and a similar way of running a business. The typology presented by these researches is first 
of all practical and explaining their nature and work is based on the prepared template of CANVAS model. The categorization covers the following types:

a) separated corporation: based on distinguishing three complimentary types of business activity, that is maintaining relationship with the customer, activity related to the infrastructure and creation of product innovations (banking sector, mobile phones);

b) long tail: business concept based on selling lower number of products belonging to a rich list of categories. It is often about cumulating the sale of a niche product (eBay, Facebook, YouTube);

c) multilateral platform: connecting separate but interrelated groups by creating conditions for interaction (Visa, Google, Microsoft Windows);

d) free model: providing, at least for one segment of customer, free offer. The costs are borne by customers belonging to another group of customers (Metro, Skype, Google);

e) open business models: these models are about cooperation with external partners in the form "from outwards to the center" or "from the center outwards" in which the company uses external ideas or forwards the unused ideas onwards.

R. McGrath (2010) proposed a division into six key categories of business models. Advertising model is about the company bearing the cost of reaching the customer and the customer does not pay for the product. The advertisers bear the activity and margin costs. The second group is the group of binding models in which the basic products are relatively cheap, and the margin is collected by way of complimentary products. The third type is the model based on promotion. It is about offering the customers a prize for purchasing a product in a form of a gift. Another type is the Freeminium model in which the basic offer is free of charge. Margins are collected from customers buying the extended versions of the product. The barter models also have been distinguished, in which the product is exchanged free of charge for another equivalent product. The last group are the gift models. The basic product is free of charge and often created by volunteers. The value is generated by offering additional services.

Presented classifications of business model are generalized. The types have been discussed in detail by, for example: O. Gassmann, K. Frankenberger and M. Csik (2013), M. Johnson (2010, pp. 3-173) and J. Linder and S. Cantrell (2000). Their analysis was made by M. Kardas (2016) by grouping the proposed business models into eleven parent categories (fig. 1).

\begin{tabular}{|c|c|c|c|}
\hline Business model types & Price & Marketing & Benefits \\
\hline Experience & Product & Chain & Financial \\
\hline Trust & Innovation & Legal instruments & \\
\hline
\end{tabular}

Figure 1. Business model types according to M. Kardas.

Source: own work on the basis of M. Kardas (2016). 
The first group is the price business models. They are focused on selling the product and price regulations. The razor and blade model can be considered one of the most popular, used for the first time at the beginning of the 20th century by Gilette (Picker, 2010). It is about proposing a cheap basic product and an expensive complimentary product. In case of Gilette, the customer when buying a razor had to buy the blades of the same company as another blade would not fit. Nowadays, this model is successfully used by manufacturers of printers and toners. From among the marketing models the white label model is quite popular. It is used by companies manufacturing the products sold under distributor's logo. This practice is used in supermarkets that sold goods under their own brand. Benefits models are characterized by easier access to products in which the customer can buy it easier than at the competition. Experience models are often based on a well-known brand and the sales or outsourcing prestige of selected elements of value chain, for example as in the model of cool brands. In product models the basic product becomes an element encouraging people to buy it. An example of such model type can be an add-on used by car dealers, where the basic product is relatively cheap, but the customer has to pay for additional equipment. Chain models focus on managing the whole chain of value creating and capturing. An example of such a model can be direct selling. It is used among others by companies dealing with direct sale of cosmetic products. It is about eliminating the intermediaries from the supply chain and collecting their margin. Intermediary models are the opposite of the chain models. Open market making is a popular chain model. In this case the company establishes a market and invites sellers and buyers, who pay commissions for carrying out the transactions, for example eBay. Trusted advisor model is an example of trust model. Such models are about offering services, at the same time maintaining strict confidentiality of business. Legal instruments models are popular in commercial or restaurant chains. One of the most well-known examples is the franchise model in which, on the basis of license and with the support of an organization, the owner bears the risk of running the business and pays the franchisor the commission. The last category is the category of financial models. To name one of the most popular models we can distinguish cash machine model in which the customers pay in advance for the product before the company bears any costs.

An example of innovative business model is the open source model where the creator shares the technology free of charge, and profits by rendering complimentary services such as technical support. Innovative business models are an interesting research subject (Wirtz 2016), which is not often linked with the technology.

We can also classify business models as divided due to the type of market relations. For example, M. Norris and S. West (2001, p. 179) make a reference to several market relations (B2C, B2B, $\mathrm{C} 2 \mathrm{C}$ or $\mathrm{P} 2 \mathrm{P}$ and $\mathrm{M}$-commerce), while others (Grefen 2010, pp. 16-32) add subsequent relations (B2A, C2B, C2A, G2B, G2C and B2R) thus creating an extended classification:

1. B2C (Business-to-Customer), means a relation aiming to win individual customers by focusing the relation on the direct recipient.

2. B2B (Business-to-Business), means focusing the relation development in the enterprise on other enterprises by concentrating on group recipients (wholesalers, contract recipients, state recipients etc.). 
3. B2A (Business-to-Administration), means the use of the transaction in which the entrepreneurs and public administration bodies are parties as a basis.

4. C2B (Customer-to-Business), a relation sometimes referred to as M-commerce (Mobile Commerce), in which the access to wireless devices is used, making it possible to carry out the transaction. It is a relation based on the opportunity of placing purchase offers to which the manufacturers can respond.

5. C2C (Customer-to-Customer), means targeting the activities to the possibility of direct exchange of goods between the consumers.

6. C2A (Customer-to-Administration), a relation between natural persons and public administration.

7. Other relations, cover such dependencies as P2P (Peer-to-Peer), using the Internet to enable direct exchange of data without the need to send them through the main server, $\mathbf{B 2} \mathbf{R}$ (Business-to-Reseller) in which the subjects of the relations are entrepreneurs and resellers, G2B and G2C, where the government is one of the sides in a relation with entrepreneurs and customers.

In the past decades, we can see the influence of new technologies, the development of which necessitates the update of the business models components (Nagumo 2002). Such an influence can result both from the expansion of the Internet (new processes, new business opportunities), new technologies of knowledge sharing (means, directions, channels) and new information technologies related to the behaviors of business and market processes participants (Duczkowska-Piasecka, 2013, pp. 132-142).

\section{Changing health resorts business}

Taking into account the nature of health resorts activities, it can be stated that among the changes influencing the shape of modern business models, in health resorts enterprises one must list some crucial ones.

The first change, clearly noticeable in the last two decades is the change in the structure of needs of persons visiting Polish health resorts. Although still in 1990s the health resort visitor model prevailed on the basis of which visitors stayed in the health resort to receive health resort services, in the following decades one can see a major share of persons in need of preventative care or sport services and of tourists who do not want a health resort treatment but who want some rest in conditions encouraging the contact with nature. It indicates changes in the health resort product structure that - although it is subject to changes from the past two decades - can hardly be considered final.

Another important aspect of changes is the system of financing the health resort activity. Multilateral character of the business partners creating the health resort product makes the relationship structure between them and the health resort visitor a very complex one. It applies both to relations between the every market participants as well as to the meaning of the health resort visitor in these relations. When the stay of the health resort visitor was fully financed by the state, 
the health resort visitor was treated objectively, as the facility funds were not subject to satisfaction of the direct beneficiary of the health resort services. The image of these relations was not better in 1990s when the attempts to market the health resort activities were made. The health resort visitor was still a consumer without any influence on the level of revenues of the health resort enterprise. Only after opening the health resort market for visitors coming to the health resort without doctor's referral, at a convenient time, upon their own decision regarding the time and place for their stay, and thus financing their stay by themselves, made the visitors' satisfaction an important factor influencing the level of entity revenue. As a result, the quality of health resort services improved.

Some limitation for the resources of the health resort enterprises were already completed privatization transformations carried out in the years 2005-2015 (Gromalska, 2015, pp. 67-90). When the state resigned from the potential in the scope of health resort infrastructure (spas, spa hospitals, or even whole health resort companies), it limited the control the state had over the implementation of social role of health resort enterprises in applying the ideas behind public health. The simultaneous development of the sector in the area of private spas and other health resort facilities (spa and wellness facilities) attracted groups of new recipients to the Polish health resorts.

The fourth aspect that could have influenced the components of the business model in the health resorts enterprise are the demographic changes that indicate a growing society of older people and those needing help in terms of the negative influence the civilization has on them (Szromek, 2011). One of the results of such a situation is the growing demand for health resort services, both in terms of treating chronic diseases and preventive treatment of elderly people and even services covering 24/7 care. An additional market segment are healthy citizens who regardless of the stereotypes present in the past decades, willingly go to the health resorts. This group of the health resort product recipients can quickly become the key one due to the significant touristic possibilities of health resorts areas. It seems that the business model should take into consideration also some assumptions concerning the needs of potential health resort visitors, meaning those persons who - for different reasons - were never treated in a health resort and express such needs. There is the need to use the growing demand for health resort services with the limited infrastructure and financial potential that suggests the necessity to optimize the usage of this potential.

When analyzing the state of current knowledge about business models, it was stated that in the view of current situation of the health resort sector the best approach would be to use the business model concept of A. Osterwalder and Y. Pigneur (2012). The main reason for this choice is the approach to resources in the mentioned model. Thus, the vast analysis of business model of health resorts enterprises should take into consideration the characteristic of 9 business components. It will be as follows:

1. Market segments within which a re-selection of key segments of health resort market will take place, taking into consideration both the needs of current and prospective health resort visitors.

2. The proposed value for the customer, based on the change of structure and components of the health resort product, taking into account current social needs and threats (threats different than before, for example on the side of digital media, social alienation, civilizational stress). 
This component will take into account also product innovation in the form of modern formula for a health resort, as well as the profiling of health resort services due to the current social threats.

3. Physical distribution channels, channels of communication and sale that did not change despite civilizational changes (the Internet, access to health promoting schemes of everyday life).

4. Relationships with the customers that need to be reviewed in terms of responsibility for spending the social insurance funds, but also in terms of building the awareness of health resort service providers of the fact that the final payer is the direct recipient of the services and not the insurer spending social funds on their behalf.

5. Revenue streams covering, among others, the value for the customer and market attractiveness of the rendered services.

6. The key tangible, intangible (information), financial and human assets being at the disposal of health resorts enterprises.

7. Key activities meaning the assumed strategic activities generating value for the customer using offered services.

8. Key partnership, resulting in new analysis of the choices made by business partners.

9. The structure of costs, either within the scope of cost-driven, meaning cost minimalization, building the value for the customer characterized by low prices and the mass character of offered products and services, or within the scope of value-driven through highly customized offer of the health resort.

\section{Conclusions}

Taking into consideration the characteristic of the health resort sector activity, one can state that the complex approach to research over modern health resort business model requires the analysis not only of the business model form but also of the key business components. Taking into account this diagnosis of the situation, the following conclusions were made:

1. Business models used in health resort facilities need to be re-defined in terms of components and business architecture, especially in terms of the occurring processes and relations, as the social changes, and with them the services reorganization in this sector, constitute the necessity to introduce changes to the health resort business model.

2. Modern health resort business model should be targeted towards the market dependency of B2C type, creating especially value for the customer, instead of the currently used approach of $\mathrm{B} 2 \mathrm{~B}$ or B2A type.

3. Modern health resort enterprise business model should take into account changes in the health resort product structure and its components, taking into account the needs of current and prospective recipients.

The role of business model in health resort enterprises is crucial due to the level of effectiveness of the service activities being carried out. Social and market changes, therefore, necessitate 
the change in the scope of components of that model. The lack of determination of an enterprise in the following changes may result in the loss of competitive advantage or even its marginalization.

This paper was published as part of the research project "A business model for health resort enterprises" No. 2017/25/B/HS4/00301, supervised and financed by the National Science Center in Poland and as part of statutory research ROZ 1:BK-231/ROZ1/2018 (13/010/BK_18/0029) at the Silesian University of Technology, Faculty of Organization and Management.

\section{References}

Al-Debei, M., El-Haddadeh, R., Avison, D. (2008). Defining the Business Model in the New World of Digital Business (pp. 8-9). Proceedings of the Fourteenth Americas Conference on Information Systems, August 14-17. Toronto, ON, Canada.

Battistella, C., Toni, A., Zan, G., Pessot, E. (2017). Cultivating business model agility through focused capabilities: A multiple case study. Journal of Business Research, 73, 65-82.

Brzóska, J. (2009). Model biznesowy - współczesna forma modelu organizacyjnego zarządzania przedsiębiorstwem. Organizacja i Zarzadzanie, 2, 5-23.

Doligalski, T. (ed.) (2014). Modele biznesu w Internecie. Teoria i studia przypadków polskich firm. Warsaw: Wydawnictwo Naukowe PWN.

Duczkowska-Piasecka, M. (ed.), Poniatowska-Jaksch, M., Duczkowska-Małysz, K., (2013). Model biznesu. Nowe myślenie strategiczne. Warsaw: Difin.

Dworak, J. (2016). Modele biznesu współczesnych przedsiębiorstw. Research on Enterprise in Modern Economy theory and practice, 4, 17-30.

Falencikowski, T. (2012). Strategia a model biznesu - podobieństwa i różnice. Prace Naukowe Uniwersytetu Ekonomicznego we Wrocławiu, 260, 80-93.

Gassmann, O., Frankenberger, K., Csik, M. (2013). The St. Gallen Business Model Navigator, Working Paper, University of St. Gallen.

Geissdoerfer, M., Savaget, P., Evans, S. (2017). The Cambridge Business Model Innovation Process. Procedia Manufacturing, 8, 262-269.

Grefen, P. (2010). Mastering e-Business. London: Routledge.

Gromalska, A. (2015). Uzdrowiska polskie i czeskie w okresie transformacji okresie transformacji w latach $1989-2013$. Cracow: Proksenia.

Iwasieczko, B. (2014). Modele biznesowe i ocena czynników ich efektywności. Prace Naukowe Uniwersytetu Ekonomicznego we Wroctawiu, 343, 154-163.

Johnson, M. (2010). Seizing the white space: Business model innovation for growth and renewal. Boston: Harvard Business School Publishing.

Johnson, W., Christensen, C., Kagerman, H. (2008). Reinventing Your Business Model. Harvard Business Review, 12 (87), 52-60.

Kardas, M. (2016). Pojęcia i typy modeli biznesu. In: K. Klincewicz (ed.), Zarządzanie, organizacje i organizowanie przegląd perspektyw teoretycznych (pp. 298-318). Warsaw: Wydawnictwo Naukowe Wydziału Zarządzania Uniwersytetu Warszawskiego.

Knop, L., Brzóska, J. (2016). Rola innowacji w tworzeniu wartości poprzez modele biznesu. Zeszyty Naukowe Politechniki Śląskiej. Organizacja i Zarządzanie, 99, 213-232.

Linder, J., Cantrell, S. (2000). Changing business models: Surveying the landscape. Institute for Strategic Change working paper, Accenture, 7-8.

Magretta, J. (2002). Why business models matter? Harvard Business Review, 5 (80), 86-92.

McGrath, R. (2010). Business Models: A Discovery Driven Approach, Long Range Planning, 43, $247-261$.

Nagumo, T. (2002). Innovative Business Models in the Era of Ubiquitous Networks, NRI Papers No. 49, 1-11. 
Nogalski, B. (2009). Modele biznesu jako narzędzia reorientacji strategicznej przedsiębiorstw, Master of Business Administration, 17, 3-14.

Norris, M., West, S. (2001). E-biznes. Warsaw: Wydawnictwa Komunikacji i Łączności.

Obłój, K. (2010). Pasja i dyscyplina strategii. Warsaw: Poltext.

Osterwalder, A., Pigneur, Y. (2010). Business Model Generation. Hoboken-New Jersey: John Wiley \& Sons.

Picker, R. (2010). The Razors and Blades Myth(s), John M. Olin Law \& Economics Working Paper No. 532, 225-255.

Prendeville, S., Bocken, N. (2017). Sustainable Business Models through Service Design. Procedia Manufacturing, 8 , 292-299.

Rusu, B. (2016). The Impact of Innovations on the Business Model: Exploratory Analysis of a Small Travel Agency. Procedia - Social and Behavioral Sciences, 221, 166-175.

Slywotzky, A., Morrison, D.J., Andelman, B. (2000). Strefa zysku. Warsaw: Polskie Wydawnictwo Ekonomiczne.

Szromek, A. (2011). Działalność turystyczno-lecznicza Zakładów Lecznictwa Uzdrowiskowego. Transformacja działalności przedsiębiorstw uzdrowiskowych w latach 1989-2010. Cracow: Proksenia.

Szromek, A.R. (2018). Changes in the management model of health care institutions in health resorts in the context of social and economic changes in the years 1989-2018. Health and Primary Care, 2 (2).

Teece, D. (2017). Business models and dynamic capabilities. Long Range Planning, 51, 1-10.

Wirtz, B., Pistoia, A., Ullrich, S., Gottel V. (2016). Business Models: Origin, Development and Future Research Perspectives. Long Range Planning, 49, 36-54.

Wiśniewski, A. (2017). Konstrukcja modeli biznesu. Acta Universitatis Nicolai Copernici. Zarzadzanie, 2, 75-85.

\section{ANALIZA MODELI BIZNESU W KONTEKŚCIE DZIAŁALNOŚCI PRZEDSIĘBIORSTW UZDROWISKOWYCH - PRZEGLĄD LITERATURY}

\author{
SŁOWA KLUCZOWE \\ STRESZCZENIE
}

Modele biznesu, uzdrowiska, przedsiębiorstwa uzdrowiskowe

Artykuł ma na celu dokonanie analizy literatury w zakresie modelowania biznesowego oraz klasyfikacji modeli biznesu odnosząc się do potrzeb przedsiębiorstw uzdrowiskowych. Omówiono rodzaje modeli biznesu i ich klasyfikacje. Odniesiono się do zmian w organizacji usług uzdrowiskowych. Podstawową metodologią przeprowadzonych badań była krytyczna analiza literatury.

Podstawowym powodem prowadzonych badań była potrzeba nowego spojrzenia na modele biznesu przedsiębiorstw uzdrowiskowych. W wielu przypadkach można zauważyć brak sformalizowanego modelu biznesu oraz potrzebę jego opisania na nowo. Często jest wymuszone zmianami warunków rynkowych przedsiębiorstw uzdrowiskowych i próbą dopasowania się do szybko zmieniającej się sytuacji gospodarczej. Sektor uzdrowiskowy charakteryzuje się modelami biznesu zależnymi od innych podmiotów tworzących ich system rynkowy.

Modele biznesu stosowane w obiektach uzdrowiskowych muszą zostać ponownie zdefiniowane pod względem komponentów i architektury biznesowej, zwłaszcza pod względem zachodzących procesów i relacji, ponieważ zmiany społeczne, a wraz z nimi reorganizacja usług w tym sektorze, stanowią konieczność wprowadzenia zmian. Współczesny model przedsiębiorstw uzdrowiskowych powinien być ukierunkowany na zależność rynkową typu, tworząc szczególną wartość dla klienta. Współczesny model biznesu przedsiębiorstw uzdrowiskowych powinien uwzględniać zmiany w strukturze produktów uzdrowiskowych i ich komponentach. 